\title{
The Role of Electrochemistry and Mineralogy in the Geotechnical Behavior of Salinized Soils
}

\author{
O Papel da Eletroquímica e da Mineralogia no Comportamento Geotécnico de Solos Salinizados
}

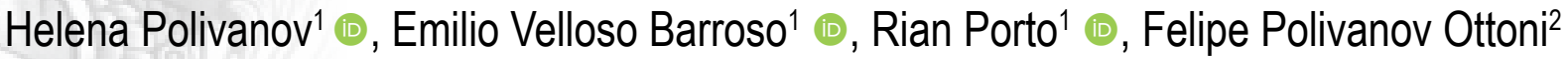 \& Thayssa Pereira de Andrade ${ }^{1}$}

${ }^{1}$ Federal University of Rio de Janeiro, Geosciences Institute, Department of Geology, Rio de Janeiro, RJ, Brazil

${ }^{2}$ Federal University of Maranhão, Center for Agricultural and Environmental Sciences, Chapadinha, MA, Brazil

E-mails: hpolivanov@gmail.com; emilio@geologia.ufrj.br; rianportodm@gmail.com; fpottoni@gmail.com;

thayssapereira94@gmail.com

\begin{abstract}
The Atterberg limits are essential information and the first step in soil classification for geotechnical purposes. Established laboratory procedures use distilled water in the plasticity and liquid limits determination. However, saline solutions frequently interact with soils in the construction environment through fluid percolation processes. This work aims to understand the variation of the geotechnical behavior of two standard materials with different mineralogical compositions (kaolinitic and smectitic) when affected by $\mathrm{NaCl}$ ionic solutions in different concentrations. The purpose is to simulate different soils in environments with the presence of saline solutions. This paper reports an experimental program in which a kaolinite-rich and a smectite-rich material received $\mathrm{NaCl}$ solutions in three different concentrations $(0.6 \%, 3.5 \%$, and $15.0 \%)$ and had their Atterberg limits determined under these conditions. Additionally, non-contaminated samples of both materials have had their limits measured using distilled water. Physical characterization tests included hygroscopic moisture, grain size distribution, grain density, plastic limit (PL), and liquid limit (LL). These data allowed the determination of the Skempton activity index (AI), plasticity index (PI), consistency index (CI), classification of soils in the Unified Soil Classification System (USCS), and in the Highway Research Board (HRB) with the group index (GI). Mineralogy was determined by X-ray diffraction and physical chemistry by measuring $\mathrm{pH}$ in $\mathrm{H}_{2} \mathrm{O}$ and $\mathrm{KCl}$, determining the $\Delta \mathrm{pH}$, the point of zero-charge ( $\mathrm{PZC}$ ), and the surface electrical potential $(\Psi \mathrm{o})$. The results show that the $\mathrm{pH}$ values rise with increasing salinity, while $\triangle \mathrm{pH}, \mathrm{PZC}, \Psi \mathrm{o}, \mathrm{LL}$, AI, PI, GI decrease with increasing salinity. The PL decreases with the increase in salinity for smectite and increases for kaolinite. The USCS and HRB demonstrate that the materials start to behave as fewer plastic materials with increased salinity. It is concluded that the variations in the physicochemical parameters of the environment control and modify the geotechnical behavior of the fine-grained soils.
\end{abstract}

Keywords: Saline environment; Physicochemical properties; Clay minerals

\section{Resumo}

Os limites de Atterberg são informações fundamentais e o primeiro passo na caracterização de solos para fins geotécnicos. Os procedimentos de laboratório utilizam a água destilada para a determinação dos limites de plasticidade e liquidez. No entanto, soluções salinas frequentemente interagem com o solo no ambiente da obra através do processo de percolação. Com este trabalho busca-se entender a variação do comportamento geotécnico de materiais-padrão com diferentes mineralogias (caulinítica e esmectítica) quando afetados por soluções iônicas de $\mathrm{NaCl}$ em diferentes concentrações. A intenção é simular diferentes solos em ambientes com a presença de soluções salinas. Este artigo descreve um programa experimental no qual materiais ricos em caulinita e esmectita receberam soluções de $\mathrm{NaCl}$ em diferentes concentrações $(0.6 \%, 3.5 \%$ e $15.0 \%)$ e tiveram seus respectivos limites de Atterberg determinados nestas condições. Adicionalmente, amostras não contaminadas de ambos os materiais tiveram seus limites medidos usando a água destilada. Os ensaios de caracterização física incluíram a umidade higroscópica, a granulometria, a massa específica dos grãos, o limite de plasticidade (LP) e o limite de liquidez (LL). Estes dados permitiram a determinação do índice de atividade de Skempton (IA), o índice de plasticidade (IP) e o índice de consistência (IC), além das classificações no Sistema Unificado de Classificação de Solos (SUCS) e no Highway Research Board (HRB), com o índice de grupo (IG). A mineralogia foi determinada por difração de raios-X e a físico-química pelo $\mathrm{pH}$ em $\mathrm{H}_{2} \mathrm{O}$ e $\mathrm{KCl}$, possibilitando o cálculo do $\Delta \mathrm{pH}$, do ponto de carga zero (PCZ) e do potencial elétrico de

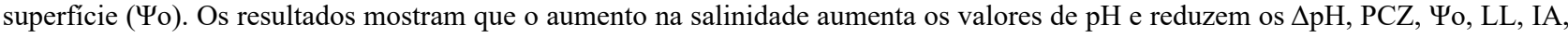
IP e IG. O LP apresenta redução com o aumento na salinidade para o material esmectítico, porém o LP aumenta no material caulinítico. As classificações SUCS e HRB mostram que os materiais se comportam menos plasticamente com o aumento da salinidade. Conclui-se que as variações nos parâmetros físico-químicos do ambiente controlam e modificam o comportamento dos solos finos.

Palavras-chave: Ambiente salino; Propriedades físico-químicas; Argilominerais 


\section{Introduction}

The water content or humidity $(\mathrm{h})$ is an essential parameter that controls behavior of fine-grained soils and affects their plasticity index (PI). The Unified Soil Classification System (USCS) recognizes water's role and considers the Atterberg limits to classify silty and clayey soils. Although it is a classification system with a long tradition of use, there are still discussions about the influence of different test methods on the liquid limit value - LL - as in the case of Casagrande apparatus and the fall cone tests (Crevelin \& Bicalho 2019; Niazi et al. 2020).

Despite the adopted procedures, soil characterization requires distilled water in the laboratory (Associação Brasileira de Normas Técnicas 2016a, 2016b; American Society for Testing and Materials 2017). However, in the construction environment, the water that percolates in the soil can transport soluble salts, altering its geotechnical behavior. The saline intrusion process is a common mechanism in the supply of soluble salts in coastal areas, with relevant consequences not only for the soil-waterplant system (Alexakis et al. 2015), but also it impacts the behavior of soils for engineering purposes in foundation projects (Elsawy \& Lakhouit 2020), earth dams (Mansouri et al. 2017), liners for the containment of contaminants (Mishra et al. 2009), and slope stability issues associated with loess soils (Xu et al. 2020).

Several researchers have studied the topic of how the soil responds to the contact with saline solutions from an engineering perspective. In his pioneer study, Stadtbäummer (1976) identified different behaviors of soils depending on the type of percolating solution and the predominant mineralogy of the soil. The author concluded that there is a more significant reduction in the LL for solutions composed of bivalent cations $\left(\mathrm{Mg}^{++}\right.$and $\left.\mathrm{Ca}^{++}\right)$compared to monovalent $\left(\mathrm{Na}^{+}\right.$and $\left.\mathrm{K}^{+}\right)$for soils with a predominance of smectites and illites. On the other hand, in kaolinitic soils, LL increases in solutions containing monovalent cations and there is a reduction in the LL values in the presence of bivalent cations.

Fontes et al. (2001) have highlighted that the mineralogical investigation and the electrical charges of colloidal particles are essential in understanding the different physicochemical phenomena in soils. These charges influence the dispersion and flocculation of colloidal systems that largely control soil geotechnical characteristics.

Arasan \& Yetimoğlu (2008) observed that the Atterberg limits decrease in the presence of salts in high plasticity clays $(\mathrm{CH})$. By the other hand, the same authors also verified an increase in the plasticity in soils composed of low plasticity clays (CL). Tajnin et al. (2014) found an increase in the LL and a reduction in the plastic limit (PL) due to the increase in natural salinity in organic and inorganic compressible silty soils.

Sen et al. (2016) verified the relationship between the chemical composition of soils and their geotechnical properties and concluded that PL and LL decrease their values as the concentration of salts increases, such that they can change their classes in the USCS. Bekkouche et al. (2018) studied the influence of salts ( $\mathrm{KCl}$ and $\mathrm{NaCl}$ ) in different concentrations on the Atterberg limits, compressibility, and the expansion potential of soil mixtures. These same authors have shown a reduction in the LL and a slight increase in the PL with an increase in salts' concentration, resulting in a significant PI reduction. Still, in these mixtures, the authors found a reduction in the mixtures' compressibility and expansion potential. Rahil et al. (2019) studied three types of clay soils with high, medium, and low plasticity, in which sodium chloride solutions percolated and which resulted in a LL reduction with an increase in the salt content. Zhou \& Lu (2021) studied correlation between Atterberg limits and soil adsorptive water, demonstrating that LL, PL, and PI were correlated to the soil's total adsorptive water.

There is probably no single reason to explain the disagreement between the results obtained by different authors. The differences between the solutions (concentrations and compositions) and the clay fraction characteristic (percentage and mineralogy) of the different soils and mixtures can explain these apparently controversial results. Of note, these previous studies have not paid attention to the characterization of soils' physicochemical aspects and their interaction with saline solutions. The relationship between soil physicochemical and its geotechnical behavior is a complex issue as it has a significant variability of factors that interfere in these relationships. The physical and chemical properties of colloids are related to surface phenomena, which depend on the amounts and nature of colloids in soils, in addition to the chemical compositions of the percolating solutions surrounding these materials. The primary characteristics of soil formation environments and those that act after their genesis can significantly influence soils' geotechnical behavior.

The electrochemical, mineralogical, and granulometric characteristics significantly influence the plasticity, cohesion, dispersion, and soils' flocculation. Most of these properties vary with the balance of the particles' 
surface electrical charges and can be reversed by changing the balance of these charges in the colloidal system. The point of zero-charge (PZC) is the $\mathrm{pH}$ value that equals in the soil, in a reversible double layer system, and the amount of positive and negative net surface charges. The superficial electric potential ( $\left.\Psi_{0}\right)$ determines the potential difference at the interface between cations and anions in the double ion layer, between the surface charges and those belonging to the diffuse layer. Bell \& Gillman (1978) found that in colloids with a permanent charge, an increase in the electrolyte concentration causes a reduction in the double layer's thickness, favoring the particles' aggregation and soil flocculation. These surface phenomena result in a decrease in the LL.

As presented in the previous paragraphs, natural soils containing diverse clay mineralogy have been investigated regarding their geotechnical behavior when percolated by different saline solutions. The diversity of compositions (saline solutions and soil clay mineralogy) has contributed to divergent and apparently contradictory results emerging from technical literature. Since kaolinite and smectite present different physicochemical behavior when in contact with saline solutions, it is mandatory to understand separately how these minerals control the basic geotechnical properties of fine salinized soils. This is the fundamental hypothesis tested in this research, which is an essential methodological step before analyzing multimineral fine-grained soils.

The goal of this work is to evaluate how the Atterberg limits vary according to the ionic solutions $(\mathrm{NaCl})$ in different concentrations in predominantly finegrained soils of different mineralogical compositions, one with low plasticity (kaolinite) and the other with high plasticity (smectite). The strategy was to reduce the number of variables that interfere in the system and seek answers to changes in geotechnical characteristics based on physicochemical parameters, such as $\mathrm{pH}$ values measured in water and in $\mathrm{KCl}, \mathrm{PZC}$ and $\Psi_{0}$. Considering this strategy, the research was designed as described below:

i. Isolate other conditions that interfere with soils' geotechnical behavior by performing analyses in a controlled environment, which justifies the use of compositionally controlled materials.

ii. Verify the changes in the geotechnical behavior of smectitic and kaolinitic materials in saline environments.

iii. Understand how the electrochemical (physicochemical) properties interfere with variations in the geotechnical behavior of kaolinitic and smectitic soils.

\section{Materials and Methods}

\subsection{Materials}

The materials used in this research are commercially available, the first composed of smectite (bentonite, from the manufacturer Bentoplus Gel) and the second composed by kaolinite (kaolin, from the manufacturer Labsyntn). We adopted them as standard or reference materials. This way, we can reduce the mineral variability of natural soils, allowing us to establish the contribution of these two common minerals to changes in soils' geotechnical behavior as a function of the content of water-soluble salts. These materials were chosen because they represent two extremes of soil activity: low in kaolinite, and high in the case of smectites.

\subsection{Methods}

We used $\mathrm{NaCl}$ (PA - pro analysis) to salinize the two materials in this study, which received aqueous solutions of this salt with the following concentrations: $0.6 \%(0.1 \mathrm{M})$, $3.5 \%(0.3 \mathrm{M})$, and $15 \%(2.6 \mathrm{M})$. This procedure resulted in four samples for each mineralogy, three contaminated with $\mathrm{NaCl}$ solutions, and one submitted to the tests using distilled water. The samples' contact with the solutions occurred inside a plastic container, which remained closed for six days. This time is considered enough to ensure uniform distribution of moisture soils-solution. Immediately after this period, the Atterberg limit tests used an aliquot of these samples, while the remaining material was air-dried for the other tests.

The X-ray diffraction (XRD) technique was applied for the mineralogical analysis of the clay fraction of commercially acquired materials. We adopted the method suggested by Jackson (1969) and analyzed the samples in their natural state, after saturation in an ethylene glycol atmosphere and after heating them at $550^{\circ} \mathrm{C}$ for 4 hours. The clay mineral analysis was performed using a D8 Advance diffractometer (Bruker) with $\mathrm{CuK} \alpha$ radiation, scintillation monochromator, $40 \mathrm{~mA}$ tube current, $40 \mathrm{kV}$ voltage, and $2^{\circ} /$ min scanning speed.

The hygroscopic moisture (h) tests followed the recommendations of the Brazilian Standards (Associação Brasileira de Normas Técnicas 2016c) and the procedures for determining the grain density and particle size distribution took into account the requirements of Associação Brasileira de Normas Técnicas (2016d). The suggested procedures presented by Associação Brasileira de Normas Técnicas (2016a, 2016b) for soil testing related to the Atterberg limits was adopted in this research. The procedures for 
physical analysis were the same for natural samples and those mixed with salts in different proportions.

The data generated in the tests mentioned above allowed us to calculate the Activity Index (AI) according to Equation 1, as proposed by Skempton (1953), and to classify natural and $\mathrm{NaCl}$ contaminated materials according to USCS and the Highway Research Board (HRB) system.

$$
A I=\frac{P I}{\%<2 \mu m}
$$

All materials had the potential of hydrogen $(\mathrm{pH})$ determined in water and $\mathrm{KCl}(1 \mathrm{~N})$ solution following the recommendations of the Empresa Brasileira de Pesquisa Agropecuária (1997), using a 1: $2.25 \mathrm{v} / \mathrm{v}$ (soil/extractor). With these data, it was possible to calculate the $\Delta \mathrm{pH}$ (Equation 2), which indicates the predominant net charge on the soil, which can be positive, neutral, or negative.

$$
\Delta p H=p H_{K C l}-p H_{H_{2} O}
$$

The PZC was calculated by Equation 3, proposed by Keng \& Uehara (1974), and the Yo, according to Nernst's simplified Equation 4 (Raij \& Peech 1972). This equation
(4) is used to the calculation of the surface potential at any $\mathrm{pH}$ as long as the PZC is known, allowing to predict how the density of charges varies with the characteristics of the suspension. The simplified Nerest equation derivation can be found in Fontes et al. (2001). With the determination of PZC and $\Psi 0$, it is possible to predict the tendency to flocculate and dispersion of soil colloids, which directly influences the physical indices used in this work. The values of PZC and $\Psi 0$ have several important applications, such as predictions about the degree of weathering and the formation of surface complexes (Sposito, 2008).

$$
\begin{gathered}
P Z C=2 * p H_{K C l}-p H_{H_{2} O} \\
\Psi_{0}=59.1\left(P Z C-p H_{H_{2} O}\right), \text { given in } \mathrm{mV}
\end{gathered}
$$

\section{Results and Discussion}

The clay fraction's mineralogy shows that smectitic material is essentially composed of smectite with traces of illite (Figure 1), while the kaolinitic material presents kaolinite with traces of illite (Figure 2).

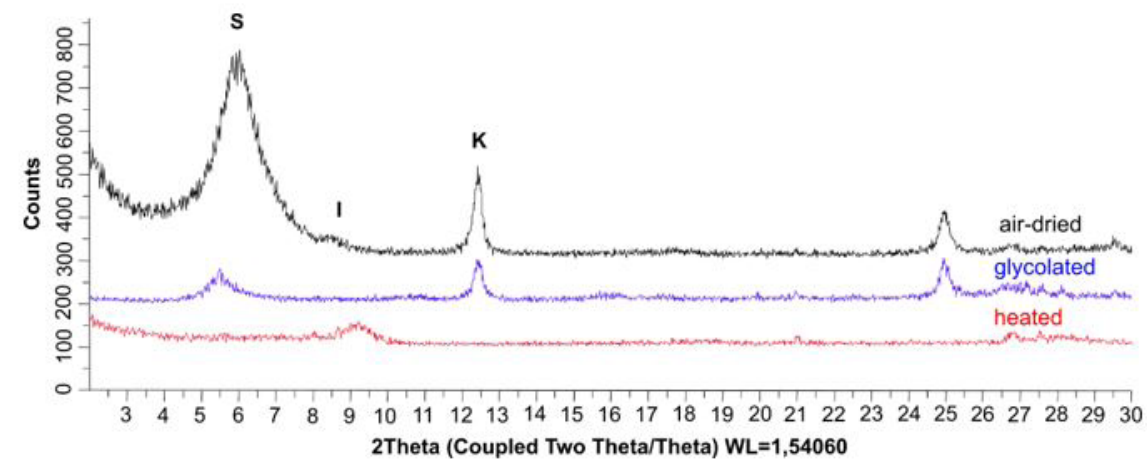

Figure 1 XRD diagram of smectite-rich material ( $\mathrm{S}$ - smectite, I - ilite, $\mathrm{K}$ - kaolinite).

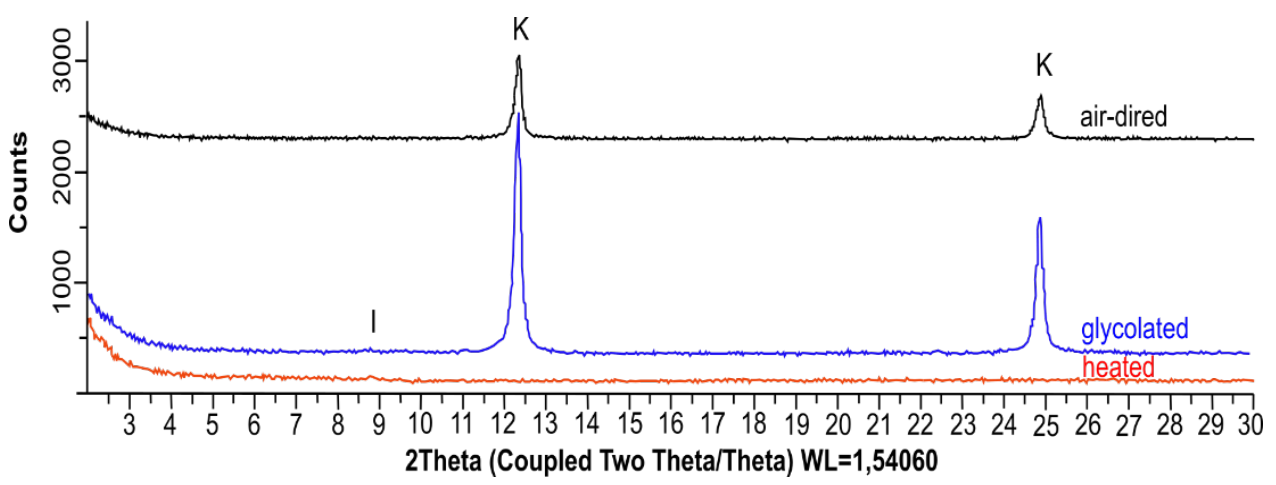

Figure 2 XRD diagram of the kaolinite-rich material ( $\mathrm{K}$ - kaolinite, I - ilite). 
The Table 1 shows the results of the physicochemical analysis. In Figure 3, it is observed that the $\mathrm{pH}$ values of the kaolinitic material are always lower than those of the smectitic material. Also, the variation of $\mathrm{pH}$ values in kaolinite is more significant than those determined in smectite. These data can be explained by the fact that kaolinites have variable (or dependent) charges; this suggests that they vary with the $\mathrm{pH}$ of the environment's solution. On the other hand, in smectite, permanent charges predominate, which practically do not vary with $\mathrm{pH}$. The $\Delta \mathrm{pH}$ values (Figure 4) are lower in smectitic material; however, there is a much more significant variation in kaolinite. The $\Delta \mathrm{pH}$ of both materials is positive, indicating that the predominant charge is positive, and, in these cases, the material tends to retain more anions than cations.

Figure 5 and Table 1 show that the smectite's PZC values are always higher than those of kaolinite. However, for both clays, these values are always higher than the $\mathrm{pH}$ in water. Once again, these data indicate that positively charged ions predominate, in agreement with Uehara \& Gillman (1980). The data variation related to increasing in $\mathrm{NaCl}$ concentration points out, for both clays, that the tendency is

Table 1 Results of physicochemical analysis.

\begin{tabular}{lccccccccccc}
\hline $\mathbf{N a C l} \%$ & kaolinite & smectite & & & & & & & \\
\hline & $\mathrm{pHH}_{2} \mathrm{O}$ & $\mathrm{pHKCl}$ & $\Delta \mathrm{pH}$ & $\mathrm{PZC}$ & $\Psi_{\mathrm{O}}(\mathrm{mV})$ & $\mathrm{pHH}_{2} \mathrm{O}$ & $\mathrm{pHKCl}$ & $\Delta \mathrm{pH}$ & $\mathrm{PZC}$ & $\Psi_{\mathrm{O}}(\mathrm{mV})$ \\
0 & 5.9 & 7.5 & 1.6 & 9.0 & 183 & 8.6 & 9.2 & 0.6 & 9.8 & 72 \\
0.6 & 6.3 & 7.4 & 1.1 & 8.5 & 130 & 8.6 & 9.2 & 0.6 & 9.7 & 67 \\
3.5 & 6.6 & 7.4 & 0.7 & 8.1 & 85 & 8.8 & 9.1 & 0.4 & 9.5 & 44 \\
15.0 & 6.9 & 7.4 & 0.6 & 8.0 & 67 & 8.8 & 9.1 & 0.4 & 9.5 & 43 \\
\hline
\end{tabular}

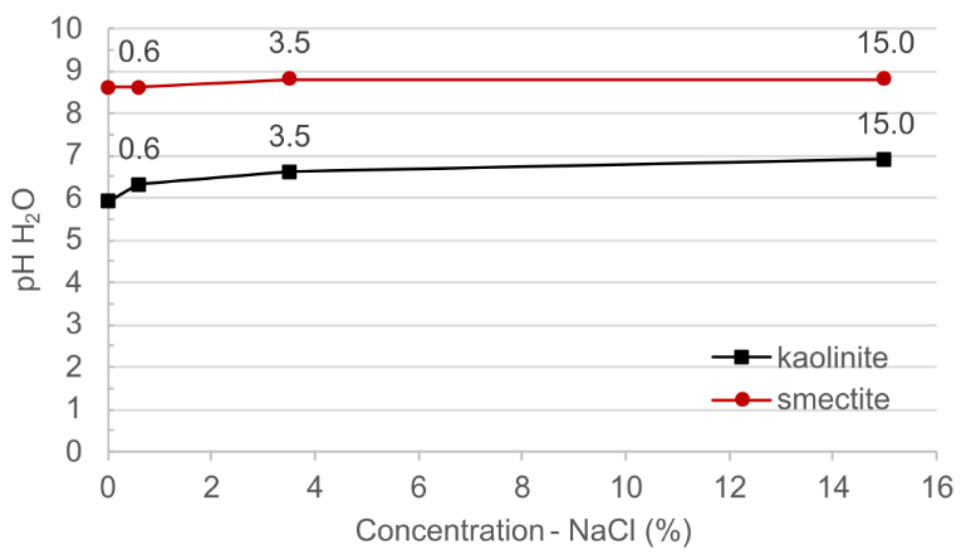

Figure 3 Changes in pH related to saline concentration.

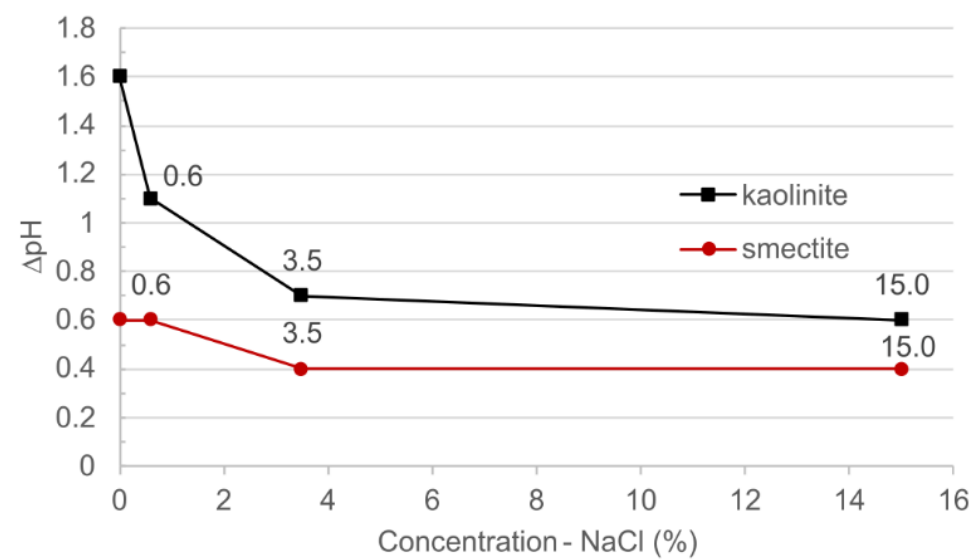

Figure 4 Changes in $\Delta \mathrm{pH}$ related to saline concentration. 
for the decrease of the PZC. This result differs from the $\mathrm{pH}$ data in $\mathrm{H}_{2} \mathrm{O}$, showing an increase in the system's negative charges. Fassbender (1980) points out that PZC is vital in soil dispersion and flocculation processes, which can reverse the net surface charge from positive to negative with increasing $\mathrm{pH}$. In this case, negative charges are created and tend to the PZC value, leading to the particles' flocculation. As known, the increase of ionic solutions' concentration promotes a reduction of the double layer, resulting in the particle's aggregation and the material flocculation. As the saline concentration increases, the PZC value approaches the water's $\mathrm{pH}$ value, favoring the particles' aggregation due to decreasing repulsion forces.

The data regarding the $\psi \mathrm{o}$ is in Table 1. Figure 6 illustrates a decrease in $\psi$ o with the increase in both materials' electrolyte concentration, although the kaolinitic material $(\psi \mathrm{o}=115.8 \mathrm{mV})$ shows a more expressive decrease than in smectitic material $\left(\psi_{0}=29.6 \mathrm{mV}\right)$. This reduction in values is related to the decrease in the thickness of the double layer.
The results of the physical and geotechnical characterization tests are in Table 2. The hygroscopic humidity (Figure 7) of the material rich in kaolinite is lower than that of the material essentially composed of smectite. The same result was achieved by Wuddivira et al. (2012). The authors demonstrate that hygroscopic moisture depends on the composition and relative frequency of each clay mineral species present in the soil. Soils in which smectites predominate have higher hygroscopic moisture values than those composed of kaolinites. This result is related to their different crystalline structures, which affect these clay minerals' physicochemical behavior. Smectite material has much higher absorption and adsorption capacities than kaolinite. Another critical factor in explaining the differences in hygroscopic humidity is the smaller particle size of the smectitic material, which demands more extended time for losing part of the hygroscopic water. The results show that the humidity is dependent on the $\mathrm{NaCl}$ concentration in the solution in the kaolinitic material, while in the smectite one, the humidity values remain almost constant (Figure 7).

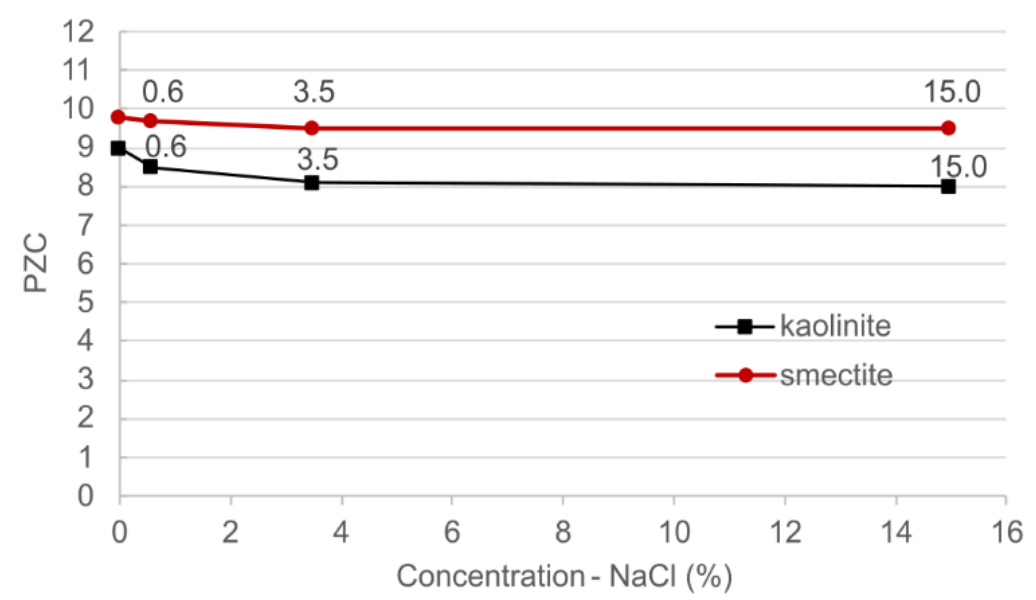

Figure 5 Changes in PZC related to saline concentration.

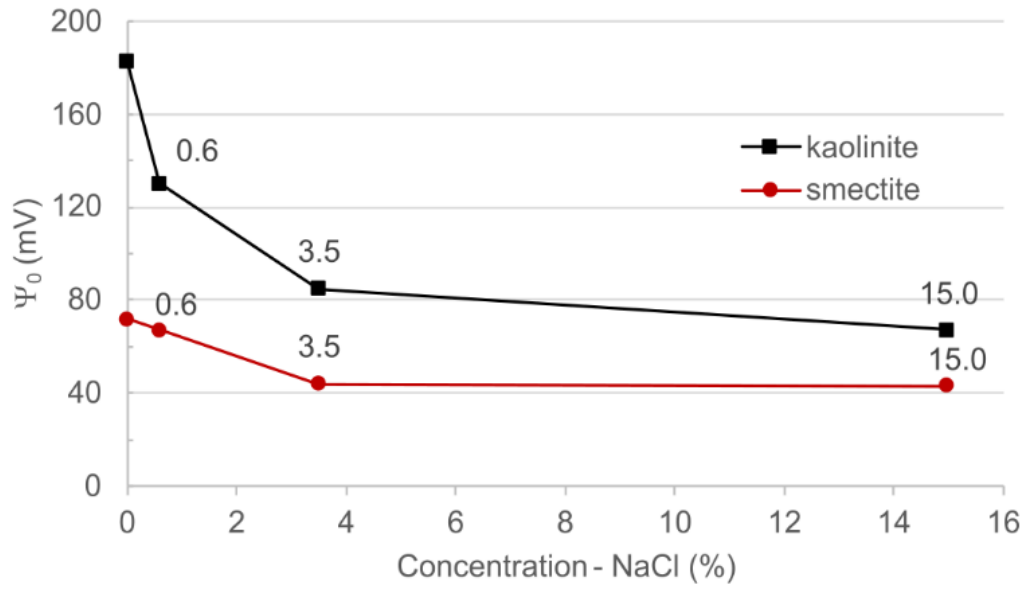

Figure 6 Changes in $\Psi_{0}$ related to saline concentration. 
Table 2 Results of physical and geotechnical characterization tests.

\begin{tabular}{|c|c|c|c|c|c|c|c|c|c|}
\hline Sample & $\mathrm{NaCl}(\%)$ & h (\%) & $\rho_{\mathrm{g}}\left(\mathrm{g} / \mathrm{cm}^{3}\right)$ & clay $(\%)$ & silt (\%) & sand (\%) & LL (\%) & PL (\%) & $\mathrm{PI}(\%)$ \\
\hline \multirow{4}{*}{ kaolinite } & 0 & 1.24 & 2.57 & 41 & 59 & 0 & 41 & 17 & 24 \\
\hline & 0.6 & 1.37 & 2.62 & 42 & 58 & 0 & 41 & 16 & 25 \\
\hline & 3.5 & 6.33 & 2.62 & 40 & 60 & 0 & 38 & 23 & 15 \\
\hline & 15.0 & 8.23 & 2.65 & 39 & 61 & 0 & 33 & 22 & 11 \\
\hline \multirow{4}{*}{ smectite } & 0 & 14.56 & 2.81 & 80 & 20 & 0 & 148 & 42 & 106 \\
\hline & 0.6 & 14.16 & 2.08 & 81 & 19 & 0 & 125 & 42 & 83 \\
\hline & 3.5 & 14.44 & 2.82 & 84 & 16 & 0 & 107 & 32 & 75 \\
\hline & 15.0 & 14.94 & 2.44 & 81 & 19 & 0 & 64 & 29 & 35 \\
\hline
\end{tabular}

The graph in Figure 8A shows that PL values are strongly affected for salt concentrations between $0.6 \%$ and $3.5 \%$, an interval in which there is a marked reduction in this consistency limit from $42 \%$ to $32 \%$ (Table 2 ). This reduction corresponds to a rate of around $32 \%$. Concentrations at the $3.5 \%$ and $15 \%$ interval induce a reduction in PL values from $32 \%$ to $29 \%$ (Table 2 ), in a milder rate $(9 \%)$. Regarding kaolinites, they present the opposite behavior observed for smectites in the range of soluble salt concentrations between $0.6 \%$ and $3.5 \%$. In this range, the value of PL experiences a significant increase from $16 \%$ to $23 \%$ (Table 2 ), which represents a $30 \%$ rate of increase. Soluble salt concentrations in the $3.5 \%$ and $15 \%$ range, $\mathrm{PL}$ variation from $23 \%$ to $22 \%$ (Table 2 ) represents almost the stability of this consistency limit. These data agree with Arasan \& Yetimoğlu (2008) work, where highly plastic materials, such as smectites, decrease the PL with increased salinity, and less plastic materials, such as kaolinite, subtly increase these values.

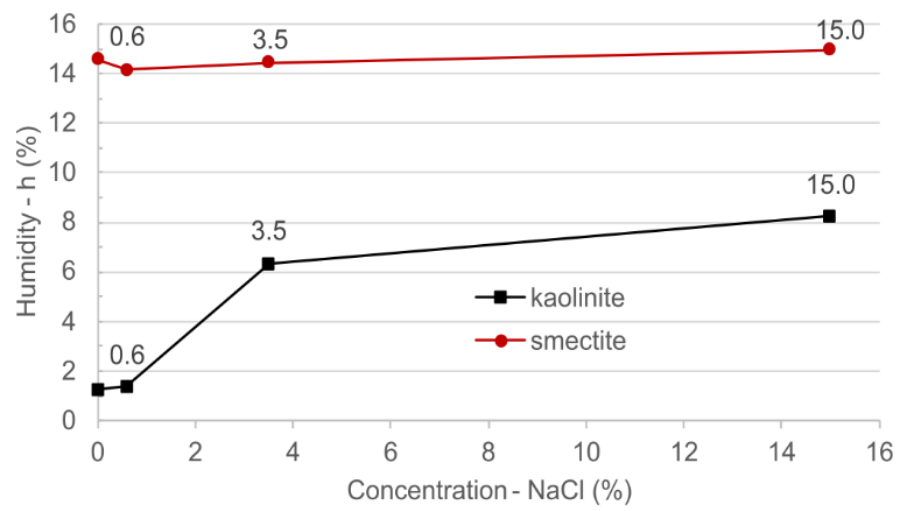

Figure 7 Changes in humidity related to saline concentration.

\section{A. Plastic limit}

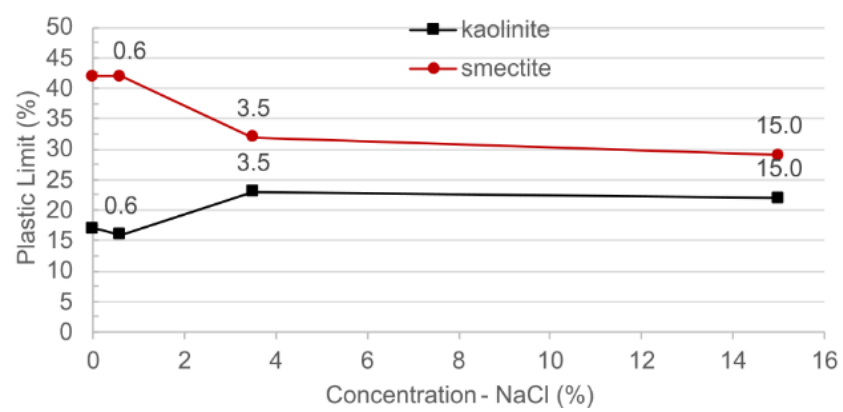

B. Liquid limit

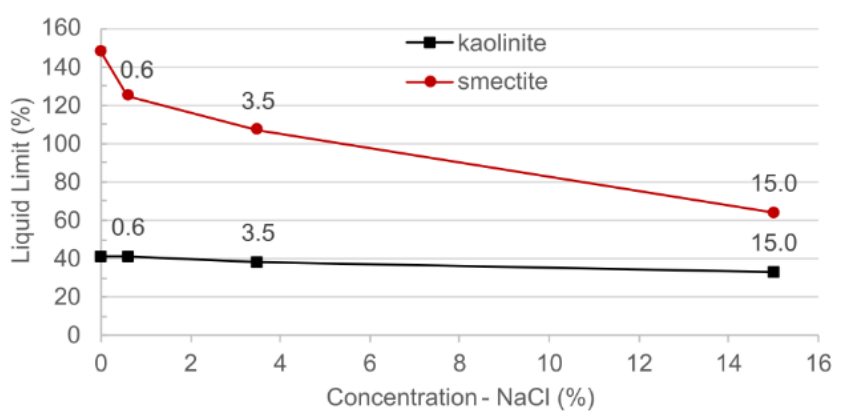

Figure 8 Changes in Atterberg related to saline concentration. A. plastic limit; B. liquid limit. 
The analysis of LL data variation (Figure $8 \mathrm{~B}$ ) shows that the kaolinites change from $41 \%$ to $33 \%$ (Table 2), which represents a reduction in the LL of about $20 \%$. In addition to higher LL values than kaolinites, smectites suffer a LL reduction from $148 \%$ to $64 \%$ (Table 2). This variation represents a drastic $57 \%$ reduction rate in $\mathrm{LL}$ values. These data follow Wuddivira et al. (2012), where bentonite presents a highly sharp drop in this index and kaolinite remains practically unchanged.

Table 3 shows the data for the classification of the PI and AI, and Figure 9 illustrates the dependence of these indices on salts' concentration. Both samples have a general tendency to reduce the PI value, the same observed by Sen et al. (2016). However, in this paper, smectite has a much more significant reduction tendency while kaolinite presents a slight decrease up to 3,5\%, and then PI becomes almost constant until $15 \%$. These findings are similar to those of Wuddivira et al. (2012). This same behavior occurs concerning Skempton's AI. Kaolinite in all analyzed salt concentrations remains inactive; however, the AI decreases sharply with salinity values above $0.6 \%$. Smectite gradually changes from active to normal, reaching inactivity sequentially with an increase in saline concentration. Sen et al. (2016) also found a decrease in PI values in kaolinitic and smectitic materials in experiments with saline solutions of $\mathrm{NaCl}, \mathrm{CaCl}_{2}$, and $\mathrm{MgCl}_{2}$. Putra et al. (2018) also showed a marked $\mathrm{AI}$ reduction against $\mathrm{NaCl}$ concentration increase.

Both materials showed a tendency to reduce plasticity with an increase in salt concentration in the solution. The kaolinite-rich material presents a slight variation compared with the smectite-rich material. In the first, the concentrations of $0 \%$ and $0.6 \%$ plot remarkably close in the graph (Figure 10), showing significant variations only above $0.6 \%$. The smectite-rich material presents a much broader variation in plasticity with $\mathrm{NaCl}$ concentration, resulting in the migration of samples from the $\mathrm{CH}$ to the $\mathrm{CL}$ field in the Unified Soil Classification System (USCS), and configuring an evident change in the geotechnical behavior of the samples. In the same way, the papers published by Arasan \& Yetimoğlu (2008) and Shariatmadari et al. (2011) showed that the soil groups in the USCS have migrated to less plastic ones.

The kaolinite-rich material presents slight variation in the classification in the Highway Research Board (HRB) system (Figure 11) with an increase in the concentration of $\mathrm{NaCl}$, showing a tendency to move from the classification

Table 3 Soil PI and Al classification related to salinity concentration.

\begin{tabular}{|c|c|c|c|c|c|}
\hline Clay & $\% \mathrm{NaCl}$ & PI & Degree of plasticity & Al & Interpretation \\
\hline \multirow{4}{*}{ kaolinite } & 0 & 24 & High plasticity & 0.59 & Inactive \\
\hline & 0.6 & 25 & High plasticity & 0.60 & Inactive \\
\hline & 3.5 & 15 & Mediumm plasticity & 0.38 & Inactive \\
\hline & 15.0 & 11 & Medium plasticity & 0.28 & Inactive \\
\hline \multirow{4}{*}{ smectite } & 0 & 106 & Very high plasticity & 1.33 & Active \\
\hline & 0.6 & 83 & Very high plasticity & 1.02 & Normal \\
\hline & 3.5 & 75 & Very high plasticity & 0.89 & Normal \\
\hline & 15.0 & 35 & High plasticity & 0.43 & Inactive \\
\hline
\end{tabular}
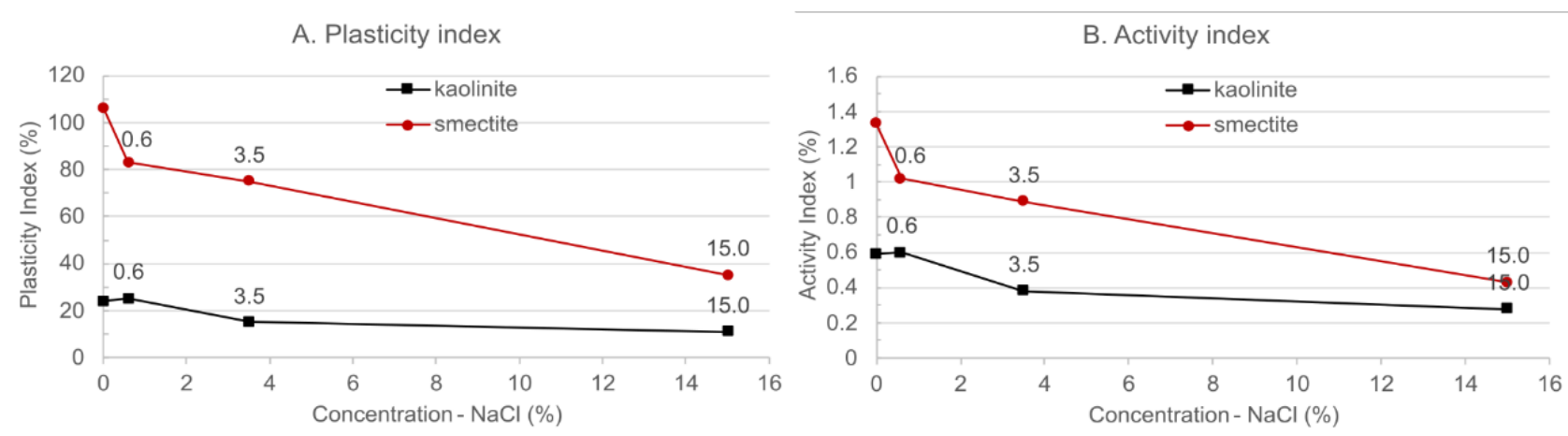

Figure 9 Changes in plasticity and activity related to salinity concentration. A. Plasticity index; B. Activity index. 
field A6 (clay material) to the limit boundary of A4 group (silty material). Low salt concentrations $(0 \%$ and $0.6 \%)$ do not cause any changes in sample positions in the HRB classification plot. However, medium to high $\mathrm{NaCl}$ concentrations $(3.5 \%$ to $15 \%)$ tends to displace samples to the A4 classification field. Otherwise, the smectite-rich material undergoes a noticeable change in geotechnical characteristics with an increase in $\mathrm{NaCl}$ concentration, showing a tendency to change from A7-5 (clay material) to A4 (silty material). The observed behavior was expected since SUCS and HRB classification systems are both based on LL and PL.
The data disclose variations in the geotechnical classification of materials as a function of the salt concentration and clay mineralogy due to their physicochemical properties and the interaction of clay minerals with the environment (represented by saline solutions). Clays in contact with $\mathrm{NaCl}$ solutions, change their properties due to variations in the double layer in the solution-clay system. The particles' interaction forces are changed by the concentration of the ionic solution and the clay minerals' structure. These interactions led to a reduction in ionic potential and plasticity, increasing the aggregation of particles and resulting in a state close to flocculation.

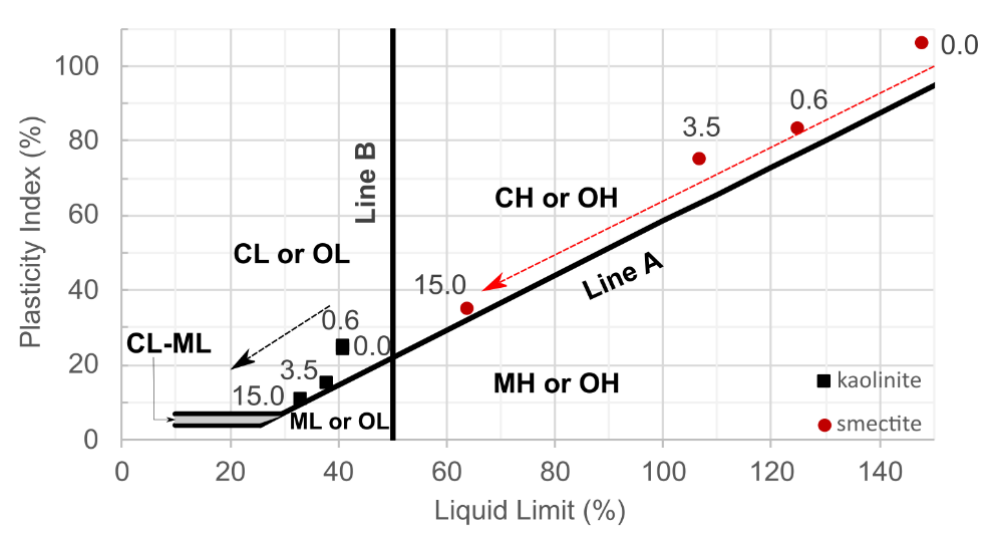

Figure 10 Samples' USCS related to salinity concentration.

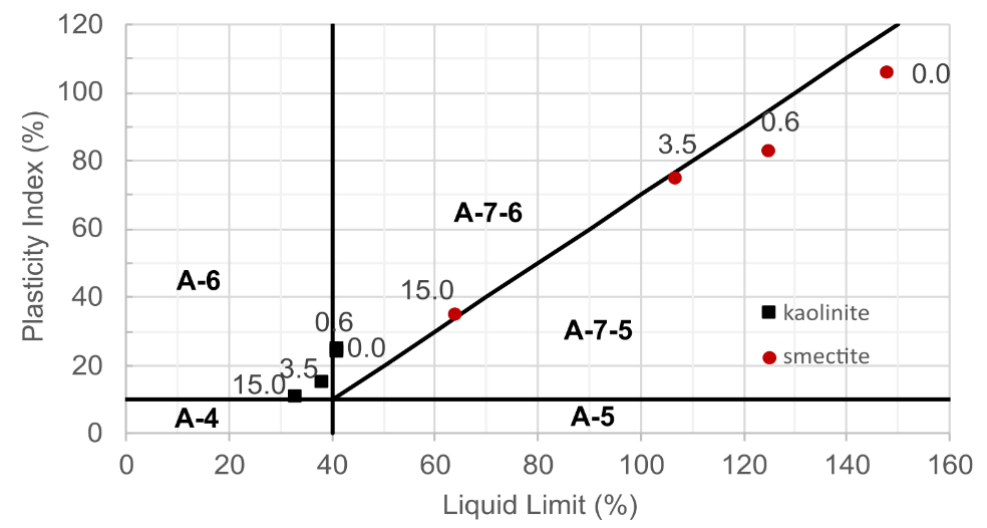

Figure 11 Samples' HRB classification related to salinity concentration.

The group index (GI) of the HRB classification (Table 4) represents the terrain's bearing capacity. This system is mainly used for the construction of road pavements. The GI varies between 0 and 20; it was intentionally allowed to exceed the upper limit to show the effects of the increase in $\mathrm{NaCl}$ concentration in the soil. In both materials, the GI decreases considerably with $\mathrm{NaCl}$ concentration (Figure 12). Once again, the smectite-rich material was more sensitive to the action of water-soluble $\mathrm{NaCl}$ salt. While the kaolinite-rich material shows GI variations above the $0.6 \%$ concentration, it appears that GI occurs immediately with the salinization of the smectite-rich material. Data and findings in the present research follow those obtained by Putra et al. (2018), in which expansive soils have their IG markedly decreased. 
Table $4 \mathrm{Gl}$ variations related to salinity concentration.

\begin{tabular}{ccc}
\hline $\mathbf{N a C l}(\%)$ & kaolinite & smectite \\
\hline 0 & 25 & 130 \\
0.6 & 26 & 103 \\
3.5 & 17 & 90 \\
15.0 & 12 & 42 \\
\hline
\end{tabular}

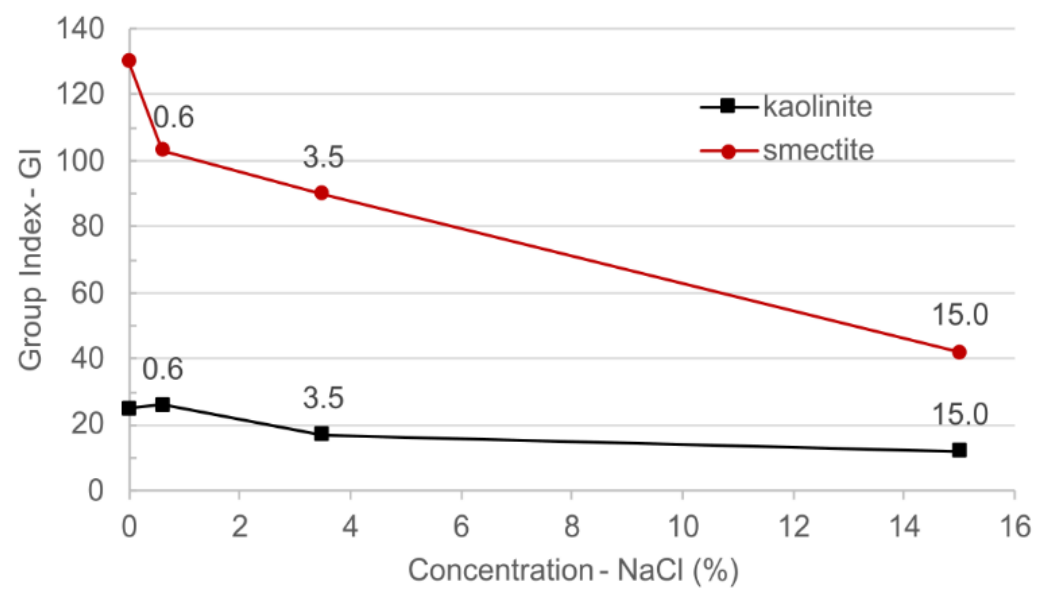

Figure $12 \mathrm{GI}$ variations related to salinity concentration.

\section{Statistical Analysis}

The software R version 4.0.2 (R Development Core Team 2020) produced the statistical analysis of the data presented in this work, while the Factoextra package helped us with the Principal Component Analysis (PCA) and the visualization of its results.

\subsection{Spearman's Rank Correlation Coefficient}

Tables 5 and 6 present the Spearman correlation matrix's results between the following geotechnical and physicochemical parameters: LL, PL, PI, AI, $\mathrm{pH} \mathrm{H}_{2} \mathrm{O}$, $\triangle \mathrm{pH}, \mathrm{PZC}, \psi \mathrm{o}$, and GI. A correlation coefficients' absolute value greater than 0.6 is considered a good indicator of dependence between the variables analyzed in this work.

There is a strong correlation between all indexes studied in the kaolinitic material (Table 5), except between the AI and the PL. Attention is drawn to the fact that the behavior of kaolinite geotechnical indexes can be explained by the soil's physicochemical parameters, considering the high correlation between them. The Physic-chemical characteristics of the environment control the behavior of kaolinitic soils.
The smectitic material (Table 6) has a strong correlation between salinity and all studied indices (LL, PL, PI, AI, $\mathrm{pH} \mathrm{H}_{2} \mathrm{O}, \Delta \mathrm{pH}, \mathrm{PZC}, \psi \mathrm{o}$, and GI). Also, in the case of bentonite, which is quite sensitive to soluble salt's presence, the soil's physicochemical parameters explain the variations of the geotechnical indexes when the soil is salinized. Thus, the environment's physicochemical characteristics control the geotechnical behavior of kaolinitic and smectitic soils.

\subsection{Cluster Analysis}

Cluster analysis is concerned with classifying data into groups. Figure 13 shows the clusters for samples rich in kaolinite (C) and smectite (B). The numbers refer to the $\mathrm{NaCl}$ concentrations in the solutions, where sequentially $1(0 \%) ; 2(0.6 \%) ; 3(1.5 \%)$ and $4(15 \%)$.

The hierarchical clustering analysis (Figure 13) of the kaolinite and bentonite samples shows differences that reflect these materials' geotechnical characterization data related to salinization. The kaolinitic material presents a sequential grouping where the samples come together in two distinct groups: low salinity and medium to high salinity. The smectitic materials show that salinization with $15 \%$ $\mathrm{NaCl}$ (B4) is the most out of line with the others, followed 
Table 5 Spearman's correlation for kaolinitic material

\begin{tabular}{|c|c|c|c|c|c|c|c|c|c|c|}
\hline & salt & LL & PL & PI & Al & $\mathrm{pH} \mathrm{H}_{2} \mathrm{O}$ & $\Delta \mathrm{pH}$ & PZC & $\Psi_{0}$ & GI \\
\hline salt & 1.00 & & & & & & & & & \\
\hline LL & -0.95 & 1.00 & & & & & & & & \\
\hline PL & 0.60 & -0.74 & 1.00 & & & & & & & \\
\hline $\mathrm{PI}$ & -0.80 & 0.95 & -0.80 & 1.00 & & & & & & \\
\hline $\mathrm{Al}$ & -0.77 & 0.82 & -0.26 & 0.77 & 1.00 & & & & & \\
\hline $\mathrm{pH} \mathrm{H}_{2} \mathrm{O}$ & 1.00 & -0.95 & 0.60 & -0.80 & -0.77 & 1.00 & & & & \\
\hline$\Delta \mathrm{pH}$ & -1.00 & 0.95 & -0.60 & 0.80 & 0.77 & -1.00 & 1.00 & & & \\
\hline PZC & -1.00 & 0.95 & -0.60 & 0.80 & 0.77 & -1.00 & 1.00 & 1.00 & & \\
\hline$\Psi_{0}$ & -1.00 & 0.95 & -0.60 & 0.80 & 0.77 & -1.00 & 1.00 & 1.00 & 1.00 & \\
\hline $\mathrm{Gl}$ & -0.80 & 0.95 & -0.80 & 1.00 & 0.77 & -0.80 & 0.80 & 0.80 & 0.80 & 1.00 \\
\hline
\end{tabular}

Table 6 Spearman's correlation for smectitic material.

\begin{tabular}{|c|c|c|c|c|c|c|c|c|c|c|}
\hline & salt & LL & $\mathrm{PL}$ & PI & Al & $\mathrm{pH} \mathrm{H} \mathrm{H}_{2} \mathrm{O}$ & $\Delta \mathrm{pH}$ & PZC & $\Psi_{0}$ & GI \\
\hline salt & 1.00 & & & & & & & & & \\
\hline LL & -1.00 & 1.00 & & & & & & & & \\
\hline$P L$ & -0.95 & 0.95 & 1.00 & & & & & & & \\
\hline $\mathrm{PI}$ & -1.00 & 1.00 & 0.95 & 1.00 & & & & & & \\
\hline $\mathrm{Al}$ & -1.00 & 1.00 & 0.95 & 1.00 & 1.00 & & & & & \\
\hline $\mathrm{pH}$ & 1.00 & -1.00 & -0.95 & -1.00 & -1.00 & 1.00 & & & & \\
\hline$\Delta \mathrm{pH}$ & -0.90 & 0.90 & 0.94 & 0.89 & 0.89 & -0.89 & 1.00 & & & \\
\hline PZC & -0.95 & 0.95 & 0.89 & 0.95 & 0.95 & -0.95 & 0.94 & 1.00 & & \\
\hline$\psi 0$ & -1.00 & 1.00 & 0.95 & 1.00 & 1.00 & -1.00 & 0.89 & 0.95 & 1.00 & \\
\hline $\mathrm{Gl}$ & -1.00 & 1.00 & 0.95 & 1.00 & 1.00 & -1.00 & 0.89 & 0.95 & 1.00 & 1.00 \\
\hline
\end{tabular}
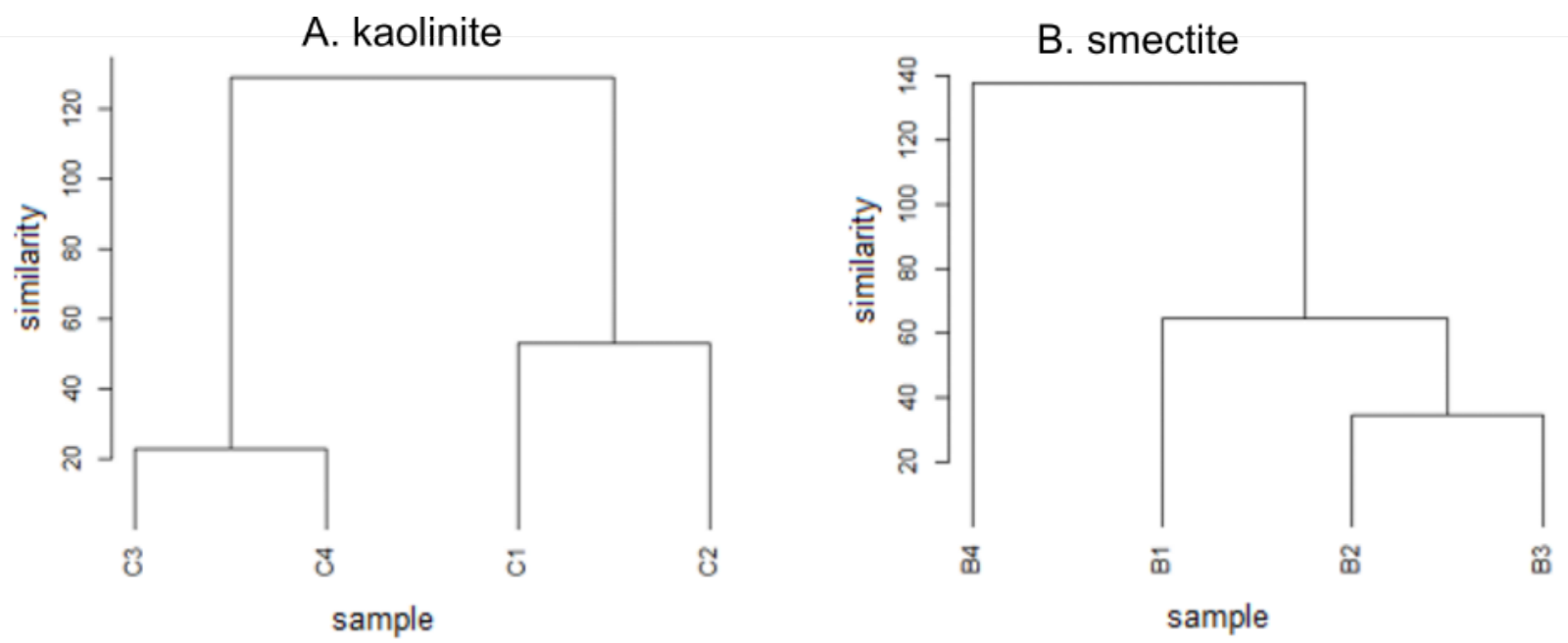

Figure 13 Dendrograms derived from cluster analysis. A. kaolinite; B. smectite. 
by the $0 \% \mathrm{NaCl}$ (B1) sample. In this material, the clusters' sequence markedly highlights the high salinity sample, once again reflecting the results of geotechnical characterization. In this high salinity condition, the smectite-rich material is located on the border of a geotechnical classification field different from the initial one, both at USCS and HRB.

\subsection{Principal Component Analysis (PCA)}

The PCA analysis of the kaolinitic material (Figure 14) shows a strong positive correlation between salinity, $\mathrm{PL}$, and $\mathrm{pH} \mathrm{H}_{2} \mathrm{O}$, showing that the increase in salinity increases $\mathrm{PL}$ and $\mathrm{pH}$ in $\mathrm{H}_{2} \mathrm{O}$. It is also possible to observe that salinity has a strong inverse correlation with the LL, AI, PI, GI, $\psi_{0}, \mathrm{PZC}$, and $\Delta \mathrm{pH}$ indices. Therefore, the increase in salinity causes a reduction in the values of these indices. In particular, the reduction in $\psi_{0}$ interferes with this material's characteristics, tending to decrease the double layer and, consequently, decreasing the LL, AI, and GI. The reduction of $\psi_{0}$ in the clay mineral surfaces affects these materials' geotechnical characteristics, making them less plastic and having a general tendency to aggregate.

The smectitic material (Figure 15) shows that the increase in saline concentration has an inverse correlation with LL, PL, PI, AI, $\psi_{0}$, PZC, $\Delta \mathrm{pH}$, and GI. The $\mathrm{pH}$ in water has a direct correlation with salinity. The smectite PCA analysis allows us to observe that the saline concentration influences the physicochemical and geotechnical characteristics of smectitic materials.

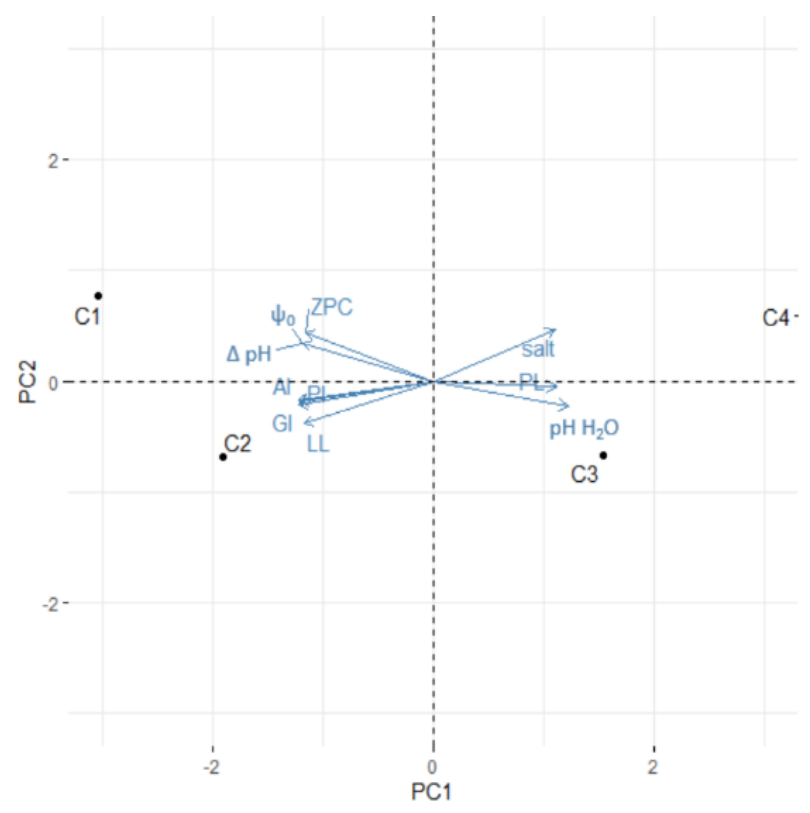

Figure 14 PCA diagram for kaolinitic material.

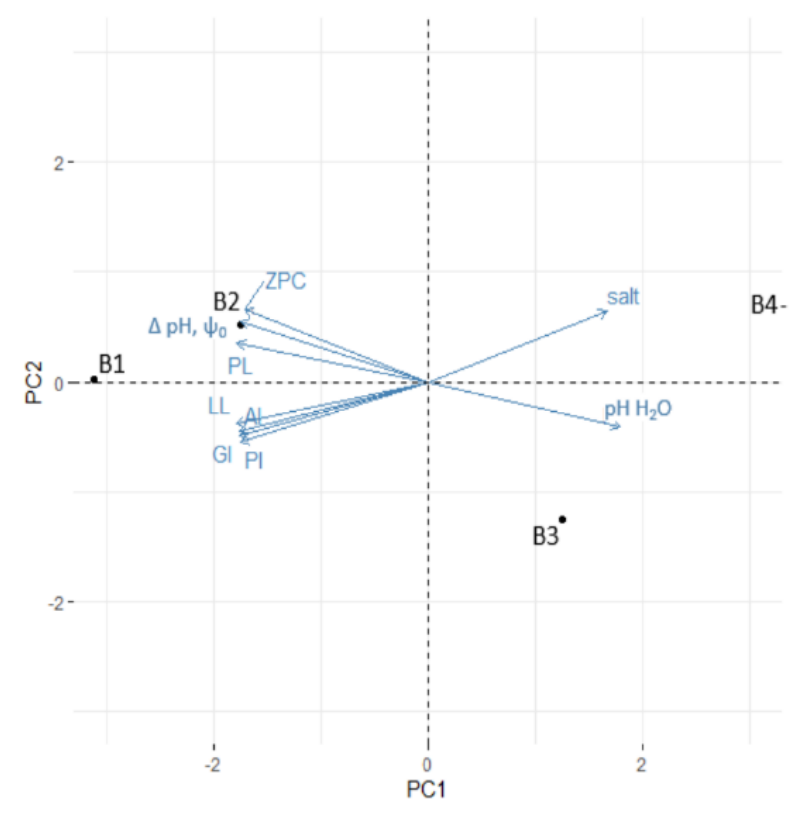

Figure 15 PCA diagram for the smectite-rich material.

\section{Conclusions}

- The results presented and discussed in this article confirm the research hypothesis related to reducing the number of variables involved in the study. Thus, it was possible to understand the changes in the geotechnical behavior of soils in the presence of saline solutions of $\mathrm{NaCl}$ at different concentrations.

- Faced with $\mathrm{NaCl}$ solution at different concentrations, kaolinite-rich and smectite-rich materials showed different geotechnical behaviors. These results highlighted that it is necessary to separately understand each clay mineral species' electrochemical behavior in natural fine-grained soils to safely assess the role they play when present in different proportions in soils.

- The study demonstrated that the environment's saline conditions modify fine-grained soils' geotechnical characteristics, reducing the double layer and making them less plastic. The chemical characteristics of the environment affect the geotechnical behavior of soils, being much more significant in expansive soils.

- The strategy of working with only one saline solution proved to be adequate. It highlighted the relevance of analyzing the physicochemical parameters of the soil ( $\mathrm{pH}, \mathrm{PZC}$, and $\Psi \mathrm{o})$ to understand its geotechnical behavior against saline solutions that percolate it. The potential of Hydrogen $(\mathrm{pH})$ is the primary variable 
of the physicochemical analysis presented here. As it is easy and quick to determine, in addition to its low cost, it must be used in conjunction with the tests for geotechnical soil characterization, using the saline solution present at the engineering project site. Indeed, for engineering purposes, the adoption of this procedure will allow an adequate prediction of the geotechnical behavior of soils subject to similar conditions in work.

\section{Acknowledgments}

We express our thanks to the National Council for Scientific and Technological Development (CNPq) for the first author's research grant (312475/2019-5) and the third author's scientific initiation scholarship (122547/2019-5).

\section{References}

Alexakis, D., Gotsis, D. \& Giakoumakis, S. 2015, 'Evaluation of soil salinization in a Mediterranean site (Agoulinitsa districtWest Greece)'. Arabian Journal of Geosciences, vol. 8, no. 3, pp. 1373-83. https://doi.org/10.1007/s12517-014-1279-0

American Society for Testing and Materials 2017, Standard Test Methods for Liquid Limit, Plastic Limit, and Plasticity Index of Soils, ASTM-D4318. 2017, American Society for Testing and Materials, Pennsylvania.

Arasan, S. \& Yetimoğlu, T. 2008, 'Effect of inorganic salt solutions on the consistency limits of two clays'. Turkish Journal of Engineering and Environmental Sciences, vol. 32, no. 2, pp. 107-15. https://journals.tubitak.gov.tr/engineering/issues/ muh-08-32-2/muh-32-2-5-0712-11.pdf

Associação Brasileira de Normas Técnicas 2016a, Solo -. determinação do limite de liquidez, ABNT-NBR 6459. 2016, Associação Brasileira de Normas Técnicas, Rio de Janeiro

Associação Brasileira de Normas Técnicas 2016b, Solo determinação do limite de plasticidade, ABNT-NBR 7181. 2016, Associação Brasileira de Normas Técnicas, Rio de Janeiro.

Associação Brasileira de Normas Técnicas 2016c, Amostras de solo - preparação para ensaios de compactação e ensaios de caracterização, ABNT - NBR 6457. 2016, Associação Brasileira de Normas Técnicas, Rio de Janeiro.

Associação Brasileira de Normas Técnicas 2016d, Solo - análise granulométrica, ABNT - NBR 7181. 2016, Associação Brasileira de Normas Técnicas, Rio de Janeiro.

Bekkouche, S.R., Boukhatem, G., Mendjel, D. \& Benayoun, F. 2018, 'Use of salt compounds for the stabilization of expansive soils'. Indian Journal of Engineering, vol. 15, pp. 250-6. https://www.discoveryjournals.org/engineering/ current_issue/2018/A25.pdf

Bell, L.C. \& Gillman, G.P. 1978, 'Surface charge characteristics and soil solution composition of highly weathered soils' in
C. S. Andrew \& E. J. Kamprath (eds), Mineral nutrition of legumes in tropical and subtropical soils, Commonwealth Scientific and Industrial Research Organisation, Melbourne, VIC, pp. 37-57

Crevelin, L.G. \& Bicalho, K.V. 2019, 'Comparison of the Casagrande and fall cone methods for liquid limit determinations in different clay soils', Revista Brasileira de Ciência do Solo, vol. 43, e0180105. https://doi. org/10.1590/18069657rbcs20180105

Elsawy, M.B.D. \& Lakhouit, A. 2020, 'A review on the impact of salinity on foundation soil of coastal infrastructures and its implications to north of Red Sea coastal constructions'. Arabian Journal of Geosciences, vol. 13, no. 13, 555. https:// doi.org/10.1007/s12517-020-05601-6

Empresa Brasileira de Pesquisa Agropecuária 1997, Manual de métodos de análise de solo, Rio de Janeiro

Fassbender, H.W. 1980, Química de suelos con enfasis en suelos de America Latina, Instituto Interamericano de Ciências Agrícolas, São José, Costa Rica.

Fontes, M.P.F., Camargo, O.A. \& Sposito, G. 2001, 'Eletroquímica das partículas coloidais e sua relação com a mineralogia de solos altamente intemperizados'. Scientia Agricola, vol. 58, no. 3, pp.627-46. https://www.scielo.br/pdf/sa/v58n3/ a29v58n3.pdf

Jackson, M.L. 1969, Soil Chemical Analysis - Advanced Course, 2nd edn, University of Wisconsin/Madison libraries, Madison.

Keng, J.C.W. \& Uehara, G. 1974, 'Chemistry, mineralogy and taxonomy of Oxisols and Uttisols', Soil and Crop Sciences Society Proceedings, pp. 119-26

Mansouri, H.; Jorkesh, Z.; Ajalloeian, R. \& Sadeghpour, A.H. 2017, 'Investigating effects of water salinity on geotechnical properties of fine-grained soil and quartz in a sandstone case study: Ajichay project in northwest Iran', Bulletin of Engineering Geology and the Environment, vol. 76, no. 3, pp. 1117-28. https://doi.org/10.1007/s10064-016-0920-4

Mishra, A.K., Ohtsubo, M., Li, L.Y., Higashi, T. \& Park, J. 2009, 'Effect of salt of various concentrations on liquid limit, and hydraulic conductivity of different soil-bentonite mixtures'. Environmental Geology, vol. 57, no. 5, pp. 1145-53. https:// doi.org/10.1007/s00254-008-1411-0

Niazi, F.S., Pinan-Llamas, A., Cholewa1, C. \& Amstutz, C. 2020, 'Liquid limit determination of low to medium plasticity Indiana soils by hard base Casagrande percussion cup vs. BS fall-cone methods'. Bulletin of Engineering Geology and the Environment, vol. 79, no. 4, pp. 2141-58. https:// doi.org/10.1007/s10064-019-01668-y

Putra, P.P., Paramiswari, D.A., Ilham, A., \& Ma'ruf, M.F. 2018, 'Expansive soil improvement of Glagahagung village, Purwoharjo sub-district, Banyuwangi district, which is chemically stabilized', 4th International Conference on Rehabilitation and Maintenance in Civil Engineering (ICRMCE 2018), MATEC Web of Conferences 195, 03009. https://doi.org/10.1051/matecconf/201819503009

R Development Core Team 2020, R: a language and environment for statistical computing, R Foundation for Statistical Computing, viewed 18 July 2020, <https://www.R-project. org/>, Vienna, Austria 
Rahil, F.H., Al-Soudany, K.Y.H., Abbas, N.S. \& Hussein, L.Y. 2019, 'Geotechnical properties of clayey soils induced by the presence of sodium chloride'. 2nd International Conference on Sustainable Engineering Techniques (ICSET 2019), IOP Conference Series: Materials Science and Engineering, vol. 518, no.2, 022064. https://doi.org/10.1088/1757$899 \mathrm{X} / 518 / 2 / 022064$

Raij, B.V. \& Peech, M. 1972, 'Electrochemical properties of some Oxisols and Alfisols of the tropics'. Soil Science Society of America Journal, vol. 36, no. 4, pp. 587-93. https://doi. org/10.2136/sssaj1972.03615995003600040027x

Sen, P., Dixit, M. \& Chitra, R. 2016, 'Effect of chemicals on index properties of soil'. International Journal of Engineering Research and General Science, vol. 4, no. 1, pp. 352-9. http:// pnrsolution.org/Datacenter/Vol4/Issue1/47.pdf

Shariatmadari, N., Salami, M. \& Fard, M.K. 2011, 'Effect of inorganic salt solutions on some geotechnical properties of soil-bentonite mixtures as barriers', International Journal of Civil Engineering, vol. 9, no. 2, pp. 103-10.

Skempton, A.W. 1953, 'The colloidal activity of clays', 3rd International Conference on Soil Mechanics and Foundation Engineering Proceedings, pp. 57-61. Zurich, Switzerland. https://www.issmge.org/uploads/ publications/1/42/1953_01_0014.pdf

Sposito, G. 2008, The chemistry of soils, Oxford University Press, New York
Stadtbäummer, F.J. 1976, 'The influence of inorganic salts on some soil mechanical parameters of clays'. Bulletin of Engineering Geology and the Environment, vol. 14, no.1, pp: 65-9

Tajnin, R., Abdullah, T. \& Rokonuzzaman, M.D. 2014, 'Study on the salinity and $\mathrm{pH}$ and its effect on geotechnical properties of soil in South-West region of Bangladesh'. International Journal of Advanced Structures and Geotechnical Engineering, vol. 3, no. 2, pp. 138-47

Uehara, G. \& Gillman, G.P. 1980, 'Charge characteristics of soils with variable and permanent charge minerals: I. Theory'. Soil Science Society of America Journal, vol. 44, no. 2, pp. 250-5. https://doi.org/10.2136/sssaj1980.03615995004400020008x

Wuddivira, M.N., Robinson, D.A., Lebron, I., Brechet, L., Atwell, M., De Caires, S., Oatham, M., Jones, S.B., Abdu, H., Verma, A.K. \& Tuller, M. 2012, 'Estimation of soil clay content from hygroscopic water content measurements'. Soil Science Society of America Journal, vol. 76, no 5, pp. 1529-35. https:// doi.org/10.2136/sssaj2012.0034

Xu, J., Li, Y., Wang, S., Wang, Q. \& Ding, J. 2020, 'Shear strength and mesoscopic character of undisturbed loess with sodium sulfate after dry-wet cycling', Bulletin of Engineering Geology and the Environment, vol. 79, no. 3, pp.1523-41. https://doi. org/10.1007/s10064-019-01646-4

Zhou, B. \& Lu, N. 2021, 'Correlation between Atterberg limits and soil adsorptive water'. Journal of Geotechnical and Geoenvironmental Engineering, vol. 147, no. 2, pp. 04020162. https://doi.org/10.1061/(ASCE)GT.1943-5606.0002463

\section{How to cite:}

Polivanov, H, Barroso, E.V., Porto, R., Ottoni, F.P. \& Andrade, T.P. 2021, "The Role of Electrochemistry and Mineralogy in the Geotechnical Behavior of Salinized Soils", Anuário do Instituto de Geociências, vol. 44: 42738. https://doi.org/10.11137/1982-3908_2021_44_42738 